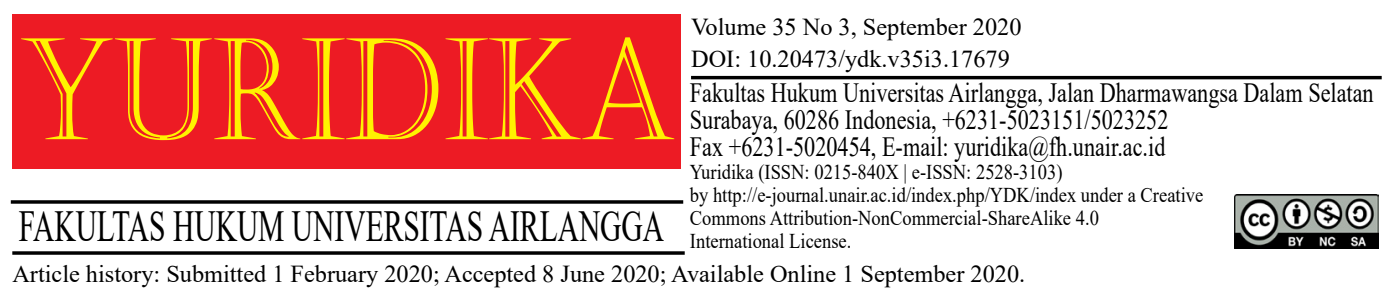

\title{
Default and Termination of Contract: a Comparative Study Between Indonesia and the UK
}

\author{
Akhmad Budi Cahyono \\ abcahyono@yahoo.com \\ Universitas Indonesia
}

\begin{abstract}
Default is something that often occurs in contractual relationship. It can be either not performing its obligations in the contract in all or in a part, performing its obligations but not in accordance with was agreed, performing its obligations but not in time, and performing something that is prohibited in the contract. Due to default, the injured party may claim compensation and/or terminate the contract. The problem is, the Indonesian Civil Code does not specify when a contract can be terminated in case of default. Therefore, it is necessary to conduct a comparative study in other countries in terms of how a default can terminate the contract. The UK which adopts common law tradition where jurisprudence is the main source of law is the right choice for conducting comparative studies. Countries with common law traditions have detailed legal rules based on jurisprudence. As in Indonesia, according to UK contract law, defaults also can terminate the contract. However, unlike in Indonesia, according to UK contract law, termination due to a default is only allowed in the event that the default is very serious. The very serious forms of default will be elaborated and become a part of the discussion in this paper.
\end{abstract}

Keywords: Contract; Defaults; Termination of Contract; Comparative Law.

\section{Introduction}

A contract or agreement is a legal event in which someone promises to another person, or two people promise each other to do or not do something. ${ }^{1}$ In practice, the parties oftenly disagree which results a default lawsuit. Due to a default, the injured party may demand fulfillment of the contract, fulfillment of the contract accompanied by compensation, compensation only, termination of the contract, termination the contract accompanied by compensation. ${ }^{2}$ So far, claims

1 Mohammad Zamroni, 'Penafsiran Kontrak Dalam Persepktif Hermeneutik' (2016) 31 Yuridika <https://e-journal.unair.ac.id/YDK/article/view/4830>. [53].

2 Subekti, Hukum Perjanjian (Intermasa 2014).[53]. 
for compensation in Indonesia have been dominated by two forms of lawsuits. The first lawsuit is based on a contractual relationship and the second is based on the existence of acts against the law or tort law. ${ }^{3}$ The problem is, there is no provision in the Act that can be a reference in terms of when a contract or an agreement can be terminated due to default. This certainly creates legal uncertainty and can result in losses for the parties bound in the contract. Debtors can be disadvantaged if due to a small negligent but ultimately the contract must be terminated due to default.

The absence of reference in terms of when a contract can be terminated due to default can also harm an innocent party if it is associated with the provisions of Article 1266 of the Indonesia Civil Code. The article requires that a court ruling in the event of a termination of the contract due to default. This will certainly be very burdensome for the innocent party if the other party's default is very serious. The very serious form of default is, for example, not fulfilling its obligations at all or deliberately it is impossible to carry out its obligations because the object of the contract has been transferred to a third party. If the innocent party dissolves the contract unilaterally due to a serious breach of the counterpart's without requested through a court, this can be considered an illegal act because it violates Article 1266 of the Indonesian Civil Code.

The unilateral termination of contract in the case of the debtor defaults without the court's permission was regulated in Article 93 of the Presidential Decree No. 70 of 2012 concerning the Second Amendment to the Presidential Decree No. 54 of 2010 concerning Procurement of Government Goods and Services. This provision allows the creditor in this case the Commitment Making Officer to terminate the contract unilaterally if the goods and services provider is unable to complete the work even though it has been given up to 50 calendar days from the performance becomes due or after being given the opportunity to complete the performance up to 50 calendar days providers of goods and services can not settle their performance. Unfortunately,

\footnotetext{
3 Faizal Kurniawan,[et.,al.], 'Unsur Kerugian Dalam Unjustified Enrichment Untuk Mewujudkan Keadilan Korektif (Corrective Justice)' (2018) 33 Yuridika <https://e-journal.unair.ac.id/ YDK/article/view/7201>.[20].
} 
these provisions are no longer stated in the new provisions of the procurement of goverment goods and services, namely Presidential Decree No. 16 of 2018.

In contrast to Indonesia, a country that adheres to common law traditions such as the UK, gives the injured party the right to terminate the contract if there is a serious default on the part of its counterpart. ${ }^{4}$ The termination is not required to go through a court. However, if the termination is brought before the court then formally it will be more beneficial for the injured party. This is because it is not easy to determine a default that is taken seriously. If the party who dissolves the agreement is not right in determining the default of the counterparty, instead the party who dissolves will be climed for a default.

Based on the statements above, this paper will analyze and compare how a default can be taken seriously then it may result in termination of the contract both in Indonesia and in the UK. The UK was chosen because it is a reference for other countries that adhered to the common law tradition. The discussion will continue with how the legal consequences of termination of the contract due to default and whether it is possible to terminate the contract if the debtor will not perform his obligation anymore.

\section{Defaults that can Terminate a Contract.}

As previously explained, the law does not specify when a default can result in the termination of contract. The law only regulates that termination of a contract due to defaults must be requested before the court as regulated in the Article 1266 of the Indonesian Civil Code. Another rule states that due to default, the injured party can demand the termination of a contract accompanied by compensation. This is as regulated in the Article 1267 of the Indoneisan Civil Code. However, this provision does not at all explain what kind of default that can terminate a contract.

Because the law does not regulate when a default can terminate a contract, the legislator requires that termination a contract due to default must be proposed before

\footnotetext{
4 Richard Stone, The Modern Law of Contract (Routledge-Cavendish 2009).[571].
} 
the court as regulated in the Article 1266 of the Indonesian Civil Code. According to Subekti, the obligation is aimed at providing an opportunity for judges to assess the extent of the debtor's negligent. ${ }^{5}$ However, these conditions will certainly be very burdensome to the creditor if the debtor's default is very serious and there is no hope of completing his obligations. In order to proposet for a termination before the court, of course the creditor must provide an ordinary lawsuit which takes a lot of time and money.

In practice, judges generally do not consider the severity of a default, but whether or not a default has occurred. If the debtor is proven to have defaulted, the judge will grant the creditor's proposal for the termination of contract. This is reflected in decision No. 267/K/Pdt/2012, between Amir Mirza Hutagalung against the Army Chief of Staff, the Commander of the Iskandar Muda Military Command, and the Head of the Iskandar Muda Military Command.

In the case between Amir Mirza Hutagalung and the Army Chief of Staff, Chief Commander of the Iskandar Muda Army Command, and Chief Engineer of the Iskandar Muda Army Command, the Supreme Court overturned the decision of the Banda Aceh High Court No 77/PDT/2010/PN.BNA which canceled the Banda Aceh District Court's ruling No. 16/Pdt.G/2008/PN.BNA. The court tried the case itself which essentially granted the Reconvention Plaintiff's claim and stated that the Defendant of Reconvention had defaulted, stating the legality of unilateral termination of the agreement dated June 20, 2006 Number: SP/13/VI/2006, as well as requiring the Plaintiff or Defendant of Reconvention to pay a sum of compensation. In this case, the Court declared the debtor defaulted because it did not complete his obligations even though it had been extended several times. However, the court did not consider the severity of the default by the debtor.

The same condition is also found in Decision No. 21/Pdt.G.S/2017/PN.Mlg between PT BRI (Persero) for the Malang Branch Office against Dewi Novita Sari and Aris Fari Kusma. In this case, the Court stated that the Defendant was in default

\footnotetext{
5 Subekti (n 2).[51].
} 
and sentenced the Defendant to pay off in full instantaneously without conditions on the entire remaining loan, both principal and interest. In its legal considerations, the judges did not consider the severity of the debtor's negligent. The Panel of Judges did not consider what percentage of the debtor's obligations had been performed so that the agreement was feasible to be terminated which resulted in the debtor having to pay their obligations immediately both in the form of principal loan and interest.

Based on the above, default is the basis for the judge to terminate a contract. The choice to continue a contract, demanding compensation or termination a contract is directed at the consideration of creditors. What is needed for the judge to either grant or reject the creditor's claims is to prove that the debtor has defaulted. The panel of judges did not consider the severity of the debtor's negligent in deciding the termination of contract due to default.

Different from the situation in Indonesia which does not regulate how a contract can be terminated due to default by the creditor, in the UK there is a doctrine which governs about this matter. This is known as the repudiatory breach doctrine. The repudiatory breach doctrine justifies the termination of contract due to a default by creditor. ${ }^{6}$

Similar to Indonesia, in the UK the default does not automatically terminate a contract even though there is a serious default that gives the injured party the right to terminate a contract. However, under UK law, to propose the termination of contract due to serious default is not required by court decision. The purpose of the regulation that a serious default does not automatically terminate the agreement is to give the injured party the choice to continue a contrcat or demand the termination of contrcat accompanied by compensation. Another reason is that the guilty party does not depend on his own negligent to benefit him in the case of the termination of contract. ${ }^{7}$ This reasoning is of course very different from Indonesia which gives the authority to the judge to assess the severity of a default that can terminate a contract.

\footnotetext{
6 Edween Peel, Treitel The Law of Contract (Sweet \& Maxweel 2011).[852].

7 ibid.[853].
} 
By not requiring a claim to terminate a contrcat should be proposed through a court, the UK's claim to terminate a contract due to default is under the decision of the innocent party. Generally the agreement has regulated in terms of how a contract can be terminated. Based on this law, the injured party may follow the procedure of termination of contract as stated in the contract or giving notice to the counterparty which is declared default.

As mentioned in the introduction, in the UK, the default of one of the parties gives the injured party the right to terminate a contract. This situation occurs when the other party's default are serious. The decision to terminate a contract is left entirely to the innocent party. The termination does not have to be proposed through a court. However, if the termination of contract due to serious default is not carried out through a court, the party demanding the termination bears the risk of a counterclaim from the counterparty. This can occur if it is not proven that the counterparty has taken a serious default.

There are several ways to determine whether a contract can be terminated due to default. ${ }^{8}$ First, the parties can agree on what form of default can terminate the contract. Second, determine the consequences of the default. Third, referring to the provisions of the laws and regulations that include a contractual obligation in that category or not.

In the UK, conditions and warranties are distinguished. Violation of conditions can result in the termination of contract. While violations of warranties only issue obligations to pay compensation to the injured party. Conditions are fundamental provisions in the contracts where violations of conditions give an innocent party the right to terminate the contract. ${ }^{9}$ Thus, condition is essential in the implementation of contract. This is different from warranties which are additional provisions so violations of warranties only issue rights to claim remedies for the injured party.

\footnotetext{
8 Richard Stone (n 4).

9 Deirdre Ni Fhoinn, 'Breach and Termination of Contract: Recent Guidance from the Courts’ (2014) 20 Commercial Law Practioner.[183].
} 
In addition to conditions and warranties, contract law in the UK also recognizes Innominate or Intermediate terms. If there is a violation of these provisions, it can result in termination of contract if the violation is sufficiently taken seriously. In the 1962 decision between Hongkong Fir Shipping and Kawasaki there was a principle that the terms of the contract were considered as intermediate terms if violations of this would prevent the innocent party from benefiting substantially from the overall contract. ${ }^{10}$

If a provision is not regulated in the provisions of the law, so it needs to be determined whether the terms include conditions or warranties, then the court has the right to determine which provisions are included in the category of conditions so as to give the right for the innocent party to terminate the contract. An important factor in relation to this is how significant it affects the purpose of the contract, whether the influence is major or minor.

Another thing to determine which provisions are conditions so that if violated gives the right to the innocent party to terminate the contract is to include it in the contract. If a provision is categorized as a condition, then the violation of that provision gives the other party the right to terminate the contract without regard to the consequences of the contract or without regard to how much it will cause harm to other parties. ${ }^{11}$

Based on the above, the agreement of the parties in determining the contract clause has an important role in determining whether or not a violation of the matter results in termination of the contract. The element of legal certainty is more prominent in the common law system than justice. When the parties have agreed in the contract then the provisions are binding, even though they are contrary to the sense of justice. The consequences arising from the violation whether the result is substantial or not on the whole agreement is not important. The court can only intervene if it is neither explicitly regulated by the parties in the contract nor the law.

\footnotetext{
10 ibid.

11 Richard Stone (n 4).[577].
} 


\section{Legal Consequence of Termination of Contract.}

As explained earlier that due to default can lead to cancellation or termination of contract. However, the termination of contract due to the debtor's default needs to be further analysed. This is especially related to the legal consequences of termination of contract.

The law in Indonesia does not explain the legal consequences of termination of contract. However, according to the doctrine, if a contract is terminated or null and void, then it will be returned to its original condition as at the time the contract was concluded. ${ }^{12}$ If there is one of the parties that has made its performance, then it is considered as undue payment as stipulated in the Article 1359 of the Indonesia Civil Code and it must be returned. ${ }^{13}$ Article 1359 of the Civil Code further states as follows: "Every payment that estimates the existence of a debt; what has been paid without indebtenes may be claimed". ${ }^{14}$

Based on the foregoing, if there is one party that has made the payment, but the contract is declared null and void due to default by the other party, then the party who has received the payment must return the payment. This is intended to restore the original condition as a result of termination of contract. J Satrio explained that the definition of payment must be interpreted broadly. The definition of payment is not only interpreted in the form of money payment, but includes the implementation of performances in the contract such as giving something or doing something that can be in the form of performance. ${ }^{15}$

The legal consequences of terminating the contract due to defaults in the country that adheres to the common law system such as the UK are different from Indonesia. In the UK, the consequence of termination of contract is not to return to the original state as when the contract was concluded (retroactive). The law in force

\footnotetext{
12 Elly Erawati and Herlien Budiono, Penjelasan Hukum Tentang Kebatalan Perjanjian (Nasional Legal Reform Program 2010).[28-29].

13 ibid.[29].

14 R Subekti and R Tjitrosudibio, Kitab Undang-Undang Hukum Perdata (Burgelijk Wetboek) (Pradnya Paramita 1992).[287].

15 J. Satrio, Hukum Perikatan: Perikatan Yang Lahir Dari Undang-Undang Bagian Pertama (Citra Aditya Bakti 1993).[80-81].
} 
in the UK are not the case. After termination of the contract, the innocent party is only no longer bound for the future performances. However, the innocent party still has the obligation to carry out obligations that are due before the contract is terminated. ${ }^{16}$ Thus, in the UK, retroactivity does not apply. As an example of this if a chartered ship has been loaded, the charterer still has the obligation to pay rent even though the contract is terminated based on the repudiatory breach doctrine.

Hence, the proper term due to default is termination of contract. This is based on the consideration that in the event of default, all rights and obligations that have been fulfilled before the contract terminated remain valid and legally binding. Likewise, obligations which are due and must be paid before the contract terminated remain legally binding and must be performed. If a contract is cancelled due to default and applying retroactive principle then the rights and obligations that have been carried out before the contract is cancelled become unclear. This can occur in long-term contracts where the rights and obligations are performed in stages.

Unlike in UK, in Indonesia if a contract is terminated due to default, then the result of the termination shall apply the retroactive principle. Based on the principle of retroactivity, to the obligations that have been carried out by one of the parties, the return can be claimed or compensated as undue payment. However, this will create problems if the contract is carried out in stages and the obligations of the parties have been carried out in certain stages. If cancellation of the contract applies retroactive principle, then what about the status of obligations that have been carried out by the parties up to a certain stage, whether it should also terminated? Thus the consequences of the termination of contract due to default as applied in the UK is more appropriate law to be applied in Indonesia.

Even though the contract has been terminated due to default, this does not rule out the possibility for innocent parties to claim compensation. In Indonesia this is in accordance with the provisions of Article 1267 of the Indonesian Civil Code. Article 1267 of the Indonesia Civil Code states:

${ }^{16}$ Edween Peel (n 6).[858-859]. 
"The party toward whom the obligation has not been complied, has the option to force the other party to comply with the obligation or to demand the dissolution of the agreement, with compensation of cost, lost or interest". ${ }^{17}$

According to the Indonesian Civil Code, there is no difference between claims for compensation caused by default and claims for compensation caused by acts against the law or tort law. ${ }^{18}$ Both the claim for compensation caused by default and the claim for compensation due to acts against the law are possible to claim the expected damages (interest). This is as regulated in Article 1246 of the Indonesian Civil Code which states:

"The cost, loss and interest which the creditor can claime consist generally of the loss that has been incurred and profit that would have been gained, subject to the exceptions and modifications mention herein below". ${ }^{19}$

Based on Article 1246 of the Civil Code, the element of compensation consists of costs, losses and interest. Costs are real expenses, such as notary fees, travel expenses and so on. Losses are the loss of creditor properties as a result of default and interest is the profit that should be obtained by creditors if there is no default. ${ }^{20}$

Similar to Indonesia, in countries that adopt a common law system such as the UK, the termination of contract due to default also does not eliminate the right of the injured party to claim compensation. Under the repudiatory breach doctrine, the innocent party has the right to choose whether to terminate the contract and demand compensation, or continue the contract even though there is a default accompanied by the right to claim compensation. ${ }^{21}$

The purpose of granting compensation in a country that adopts a common law system like the UK is the same as in Indonesia, namely placing the innocent party into a state if the contract is implemented (restitution in integrum). ${ }^{22}$ Thus, the

\footnotetext{
${ }^{17}$ R Subekti and R Tjitrosudibio (n 14).[274].

${ }_{18}$ Rosa Agustina, Perbuatan Melawan Hukum (Program Pascasarjana Fakultas Hukum Universitas Indonesia 2003).[71].

${ }^{19}$ R Subekti and R Tjitrosudibio (n 14).[270-271].

${ }^{20}$ R Setiawan, Pokok-Pokok Hukum Perikatan (Binacipta 1994).[23].

${ }^{21}$ Richard Stone (n 4).[582].

22 ibid.[593].
} 
element of compensation due to default is the same as in Indonesia including loss of profit (expectation interest).

\section{Termination of the Agreement before the Due Date.}

In a contract, it may occur that the debtor will default even if the obligation not becomes due. This can be caused by the debtor does not want or can not longer carry out their obligations in a contract. In a sale and purchase contract, for example, the debtor transfers the object sold to a third party before it is delivered to the buyer. If this happens, the creditor will be seriously harmed if he has to wait for his obligations becomes due even though the debtor has no desire to carry out his performances.

In Indonesia, there is no provision that regulates whether creditors may terminate a contract and claim compensation if the debtor no longer wishes or is unlikely to carry out his performance. That is, according to the provisions of the law in Indonesia, the debtor can not be considered default before his obligation becomes due and he does not carry out or not fulfill his obligations in the contract.

Different from Indonesia, in a country that adopts a common law system such as the UK, if one party indicates a default, then the other party has the right to terminate a contract and demand compensation. This is in accordance with the doctrine of anticipatory breach. ${ }^{23}$ According to the anticipatory breach doctrine, the injured party has the right to claim compensation in its entirety before the obligation becomes due. This is as stated in the case of Hochster v. De La Tour. In the case Lord Cambell, C.J. states:

"On this motion in arrest of judgement the question arises, whether if there be an agreement between $\mathrm{A}$ and $\mathrm{B}$, whrereby $\mathrm{B}$ engages to employ $\mathrm{A}$ on and from a future day for a given period of time, to travel with him into foreign country as a courier, and to start with him in that capacity on that day, A being to receive a monthly salary during the continuance ofsuch service, B may, before the day, refuse to perform the agreement and break and renounce it, so as to entitle A before the day to commence an action against B recover

${ }^{23}$ ibid. [583]. 
damages for breach of the agreement; A having been ready and willing to perform it, till it was broken and renounced by B". ${ }^{24}$

Based on the foregoing, A has the right to file a lawsuit against $\mathrm{B}$ who no longer wishes to employ A even though the time to hire A is not yet due. This means, in fact, B cannot be declared a default, even though it has been confirmed that this will happen because B does not want to carry out the agreement he has agreed with $\mathrm{A}$.

The anticipatory breach doctrine cannot be applied in Indonesia based on at least two reasons. First, to claim the defaulting debtor, then there must be a default statement in advance from the creditor. Secondly, to terminate a contract due to default must be proposed before the court. Thus, even if the injured party will claim for the other party in the case of default, then the claim is not based on the indication of default, but is based on an illegal act or tort law. Action of B, as reflected in the case above, can be claimed on the basis of an unlawful conduct caused by terminating the contract unilaterally.

Regarding default statements which become a barrier to the implementation of the anticipatory breach doctrine, it is regulated in the Article 1243 of the Indonesian Civil Code. Article 1243 of the Indonesian Civil Code states:

"Compensation of cost, lost and interest due to breach of an obligation shall only be obligated, if the debtor after being declared in default, still defaults to fulfill that obligation or if in his obligation to give something or to do something, he gives or does it after the expiration date". ${ }^{25}$

M Yahya Hararap states that the right to claim compensation was only effective after the debtor was declared default. Obligations of compensation (schade vergoeding) do not automatically arise at the time of default. ${ }^{26}$ Based on these statements, it is not possible for a debtor to be declared default and therefore creates an obligation to pay compensation if the obligation to carry out his performace has not become due.

\footnotetext{
${ }^{24}$ Herbert R. Limburg, 'Anticipatory Repudiation of Contract' (1925) 10 Cornel L .Rev.[136].

${ }^{25}$ R Subekti and R Tjitrosudibio (n 14).[270].

${ }^{26}$ M Yahya Harahap, Segi-Segi Hukum Perjanjian (Alumni 1996).[61].
} 
According to the UK law, refusal to carry out the performance does not have to be in real terms but can occur in the form of an act that indicates an unwillingness to carry out the performance even though it can be done by the debtor. ${ }^{27}$ Silent action or not doing something of his obligations can indicate refusal of performance, unless the debtor takes positive steps to eliminate this assumption. ${ }^{28}$

In relation to the anticipatory breach doctrine, defaults do not occur automatically, but require action or acceptance from the injured party. The act or acceptance can be in the form of a claim for compensation or by giving a notice stating the non-performance of a party to a default. ${ }^{29}$

\section{Conclusion.}

In Indonesia, the law does not specify when an act of default can result in the termination of the contract. The thing regulated by law is the termination of the contract due to defaults that must be proposed before the court as regulated in Article 1266 of the Indonesia Civil Code. Another rule states that due to default, the injured party can demand the termination of the contract accompanied by compensation. This is as regulated in the Article 1267 of the Indonesian Civil Code. However, this provision does not at all explain what kind of default that can result in the termination of contract. In practice, judges generally do not consider the severity of a default, but whether or not there has been a default. If the debtor is proven to have defaulted, the judge will grant the creditor's request for termination of the contract.

This is different from the UK. In the UK contract law, conditions and warranties are distinguished. Violation of conditions can result in the termination of the contract. While violations of warranties only issue obligations to pay compensation to the injured party. Conditions are fundamental provisions in the contracts where violations of conditions give rights to innocent parties to terminate the contract. Thus, condition is essential in the implementation of the contract. This is different

\footnotetext{
${ }^{27}$ Edween Peel (n 6).[840].

${ }_{28}$ ibid.[840-841].

${ }^{29}$ ibid.[842].
} 
from warranties as additional provisions so violations of warranties only issue the right to claim compensation for the injured party.

In the event that the agreement is terminated due to default, then both laws in Indonesia and the UK allow the creditor to claim compensation. However, the legal consequences of termination are different. In Indonesia, as a result of the termination of the contract due to default, it is returned to its original state. In the event that one of the parties has performed his obligation, it becomes an indebtedness payment or undue payment, giving rise to the obligation to return what has been received. This is different from England. In the UK, if a contract is terminated due to a default then it will only release the parties from the obligation after the contract is terminated. While obligations that have been carried out before the contract terminated remain valid and legally binding.

Legal provisions in Indonesia also do not recognize the termination of contract if the debtor does not want or is no longer possible to carry out his performances. This is different from what applies in the UK. In the UK, in the event that the debtor does not want or is no longer possible to carry out his performances, the innocent party can terminate the agreement before the obligation becomes due. This is known as the anticipatory breach doctrine.

\section{Bibliography}

Deirdre Ni Fhoinn, 'Breach and Termination of Contract: Recent Guidance from the Courts' (2014) 20 Commercial Law Practioner.

Edween Peel, Treitel The Law of Contract (Sweet \& Maxweel 2011).

Elly Erawati and Herlien Budiono, Penjelasan Hukum Tentang Kebatalan Perjanjian (Nasional Legal Reform Program 2010).

Faizal Kurniawan,[et.,al.], 'Unsur Kerugian Dalam Unjustified Enrichment Untuk Mewujudkan Keadilan Korektif (Corrective Justice)' (2018) 33 Yuridika $<$ https://e-journal.unair.ac.id/YDK/article/view/7201>.

Herbert R. Limburg, 'Anticipatory Repudiation of Contract' (1925) 10 Cornel L .Rev. 
J. Satrio, Hukum Perikatan: Perikatan Yang Lahir Dari Undang-Undang Bagian Pertama (Citra Aditya Bakti 1993).

M Yahya Harahap, Segi-Segi Hukum Perjanjian (Alumni 1996).

Mohammad Zamroni, 'Penafsiran Kontrak Dalam Persepktif Hermeneutik' (2016) 31 Yuridika $<$ https://e-journal.unair.ac.id/YDK/article/view/4830>.

R Setiawan, Pokok-Pokok Hukum Perikatan (Binacipta 1994).

R Subekti and R Tjitrosudibio, Kitab Undang-Undang Hukum Perdata (Burgelijk Wetboek) (Pradnya Paramita 1992).

Richard Stone, The Modern Law of Contract (Routledge-Cavendish 2009).

Rosa Agustina, Perbuatan Melawan Hukum (Program Pascasarjana Fakultas Hukum Universitas Indonesia 2003).

Subekti, Hukum Perjanjian (Intermasa 2014).

HOW TO CITE: Akhmad Budi Cahyono, 'Default and Termination of Contract: a Comparative Study Between Indonesia and the UK' (2020) 35 Yuridika. 
--This page is intentionally left blank-- 